\title{
Cegah Masalah Gizi Anak dengan Sosialisasi Pemberian Makanan Bayi dan Anak
}

\author{
Prevent Child Nutrition Problems with Infant and Young Child Feeding Socialization
}

Rahayu Widaryanti*
Department of Midwifery, Universitas
Respati Yogyakarta, Yogyakarya, DI
Yogyakarta, Indonesia
*email: rwidaryanti@respati.ac.id
Kata Kunci
Inisiasi Menyusui Dini
ASI Eksklusif
Makanan Pendamping ASI
Pemberian Makan Bayi dan Anak
Keywords:
Early Breastfeeding Initiation
Exclusive breastfeeding
ASI Complementary Foods
Infant Young and Child Feeding
Received: June 2019
Accepted: August 2019
Published: September 2019

\begin{abstract}
Abstrak
Kegiatan pengabdian kepada masyarakat ini bertujuan untuk memberikan pengetahuan kepada ibu tentang pemberian makan bayi dan anak untuk mencegah permasalahan gizi anak. Kegiatan Pengabdian ini dilaksanakan di balai pertemuan warga Desa Maguwoharjo, Depok, Sleman, DI Yogyakarta. Sebelum dilakukan sosialisasi responden mengisi pretest terlebih dahulu dan setelah sosialisasi mengisi post test. Olah data dilakukan dengan uji Paired Sample t-Test. Melalui program ini pengetahuan masyarakat tentang pemberian makan bayi dan anak dapat meningkat.
\end{abstract}

\begin{abstract}
Community service activities aim to provide knowledge to mothers about infant and child feeding to prevent child nutrition problems. This community service activity was held at the meeting hall of Maguwoharjo village residents, Depok, Sleman, DI Yogyakarta. Before the socialization, respondents filled the pretest first and after the socialization filled the post-test. Data processing is done by Paired Sample t-Test. Through this program, community knowledge about infant and child feeding can be increased.
\end{abstract}

(C) 2019 Authors. Published by Institute for Research and Community Services Universitas Muhammadiyah Palangkaraya. This is Open Access article under the CC-BY-SA License (http://creativecommons.org/licenses/by-sa/4.0/). DOI: https://doi.org/10.33084/pengabdianmu.v4i2.890.

\section{PENDAHULUAN}

Indonesia mengalami masalah gizi ganda, disatu sisi terdapat status gizi kurang dan kelebihan gizi. Masalah status gizi secara langsung dipengaruhi oleh konsumsi pangan dan penyakit, secara langsung dipengaruhi oleh pola asuh ketersediaan pangan, sosial ekonomi serta budaya dan politik (Hardianti et al., 2018; Sholikah et al., 2017). Menurut data WHO 60\% kematian anak balita disebabkan oleh keadaan kurang gizi dan 2/3 diantaranya disebabkan oleh pemberian makan yang kurang tepat. (Murtiyarini et al., 2014; WHO/UNICEF,
Kabupaten Sleman pada tahun 2017 prevalensi gizi buruk dan kurang sebanyak 7,33\% masih tinggi dibandingkan dengan renstra Kabupaten Sleman tahun 2017 sebanyak 7,24\%. Sedangkan di wilayah kerja Puskesmas Depok I sebanyak 7,3\%. Prevalensi balita gemuk di Kabupaten Sleman juga masih tinggi yaitu 5,72\% sedangkan di wilayah kerja Puskesmas Depok I Sebanyak 7,68\% (Dinas Kesehatan Kabupaten Sleman, 2018). Permasalahan gizi lebih harus segera mendapatkan penanganan karena akan membawa dampak yang kurang baik dalam proses siklus kehidupan seseorang dan pembentukan generasi yang 
akan datang serta meningkatkan risiko penyakit menular maupun tidak menular (Di Renzo et al, 2015). Upaya untuk menurunkan prevalensi gizi kurang dengan Pemberian Makanan Bayi dan Anak (PMBA) yang benar, dimulai dari inisiasi menyusu dini (IMD), dilanjutkan dengan pemberian Air Susu Ibu (ASI) eksklusif dan pemberian makanan pendamping ASI yang tepat sesuai umur, jumlah dan teksturnya (Khatoon et al., 2011). Tujuan dari kegiatan Pengabdian kepada masyarakat ini adalah untuk memberikan pengetahuan kepada para ibu tentang pemberian makanan pada bayi dan anak guna mencegah permasalahan gizi yang ditimbulkan akibat malnutrisi. Adapun lokasi kegiatan Pengabdian yang dilakukan adalah di Desa Maguwoharjo, Depok, Sleman, Yogyakarta.

\section{METODOLOGI}

Kegiatan pengabdian ini dilaksanakan di balai pertemuan warga desa Maguwoharjo, Depok, Sleman, DI Yogyakarta. Metode yang digunakan dalam pengabdian ini adalah penyuluhan tentang pemberian makan bayi dan anak yang meliputi inisiasi menyusu dini, ASI eksklusif, makanan pendamping ASI dan pemberian ASI hingga dua tahun (Widaryanti, 2019a). Peserta pada pengabdian ini adalah ibu-ibu yang memiliki anak usia dibawah dua tahun sejumlah 32 orang.

Pada kegiatan ini peserta sebelum mendapatkan sosialisasi mengikuti pre-test terlebih dahulu dengan tujuan mengukur tingkat pengetahuan ibu tentang PMBA. Setelah selesai mengerjakan pre-test ibu diberikan sosialisasi mengenai PMBA yang meliputi pentingnya IMD, pemberian ASI eksklusif, dan pemberian MP ASI yang tepat dan pentingnya memberikan ASI hingga dua tahun. Media yang digunakan pada pengabdian ini adalah materi dalam bentuk power point, $L C D$ projector, laptop, dan leaflet. Setelah mengikuti sosialisasi maka peserta mengikuti post-test yang bertujuan untuk mengukur tingkat pengetahuan ibu setelah mengikuti sosialisasi.

\section{HASIL DAN PEMBAHASAN}

Sebelum kegiatan sosialisasi pemberian makan bayi dan anak untuk mencegah permasalahan gizi anak dimulai peserta mengisi daftar hadir dan mengisi lembar pre test yang telah dibagikan, hal ini bertujuan untuk mengetahuan tingkat pengetahuan ibu sebelum dilakukan sosialisasi pemberian makan bayi dan anak untuk mencegah permasalahan gizi anak. Sosialisasi dilakukan selama 45 menit, adapun rincian materi berupa inisiasi menyusu dini, ASI eksklusif, MP ASI dan pemberian ASI hingga 2 tahun. Setelah acara sosialisasi selesai maka peserta mengisi lembar post test dengan tujuan mengetahui perubahan pengetahuan peserta setelah mengikuti kegiatan.

Sosialisasi diikuti oleh 33 orang ibu-ibu di Desa Maguwoharjo, Depok, Sleman, DI Yogyakarta. Sebelum penyuluhan terlebih dahulu dilakukan pre-test untuk mengetahui sejauh mana pengetahuan peserta tentang pemberian makan bayi dan anak. Dari hasil pre-test yang dilakukan terdapat ibu yang memiliki pengetahuan kurang sebanyak 9 orang, pengetahuan cukup sebanyak 14 orang dan 10 orang mempunyai pengetahuan baik. Setelah penyuluhan dilakukan post-test untuk mengetahui adanya peningkatan pengetahuan pada peserta. Dari hasil olah data yang dilakukan ibu yang mempunyai tingkat pengetahuan kurang menjadi 3 orang, 14 orang mempunyai tingkat pengetahuan cukup dan 16 orang mempunyai tingkat pengetahuan yang baik. Dari hasil tersebut dapat diketahui bahwa terdapat peningkatan pengetahuan pada peserta setelah dilakukan penyuluhan. Peningkatan pengetahuan dipastikan lagi dengan melakukan analisis menggunakan Paired Sample t-Test (T test). Didapatkan 
hasil $\mathrm{p}$ value 0.000 sehingga dapat disimpulkan adanya pengaruh sosialisasi terhadap peningkatan pengetahuan peserta tentang pemberian makan bayi dan anak, sehingga dapat mencegah permasalahan gizi yang ada di masyarakat. Berikut adalah hasil olah data pre-test dan post-test yang secara berturut-turut disajikan pada Tabel I dan Gambar 1.

Tabel I. Karakteristik Responden Berdasarkan Umur dan Paritas

\begin{tabular}{lcc}
\hline \multicolumn{1}{c}{ Karakteristik Responden } & n & Persentase (\%) \\
\hline$\underline{\text { Umur }}$ 20-35 Tahun & 27 & 81,8 \\
>35 Tahun & 6 & 18,2 \\
Total & 33 & 100 \\
Paritas & & \\
Primipara & 9 & 27,3 \\
Multipara & 23 & 69,7 \\
Grandemultipara & 1 & 3 \\
Total & 33 & 100 \\
\hline
\end{tabular}

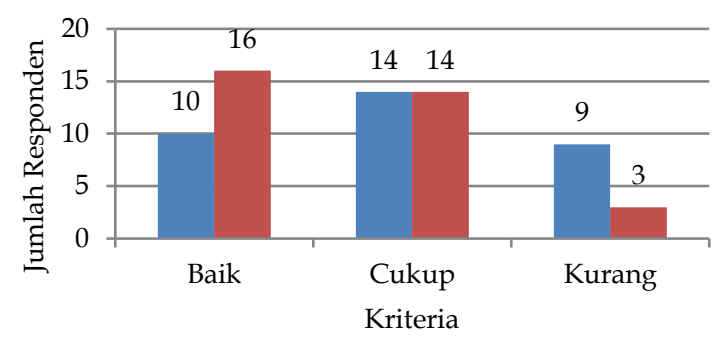

- Sebelum Sosialissasi $\quad$ Setelah Sosialisasi

Gambar 1. Perbandingan kriteria tingkat pengetahuan responden tentang PMBA sebelum dan sesudah kegiatan sosialisasi

Inisiasi menyusu dini sangat membantu bayi dalam memenuhi kebutuhan nutrisi di awal kehidupannnya, dengan IMD bayi akan mendapatkan kolostrum untuk kekebalan bayi (Permatasari et al., 2016). Selain itu terdapat penelitian yang menyatakan bahwa IMD akan menentukan kesuksesan dalam pemberian ASI eksklusif, dimana ibu yang mendapatkan konseling mengenai IMD sebelum hamil dan selama hamil maka akan melakukan IMD dengan baik, sebaliknya ibu yang tidak menikah, melahirkan secara Sectio Caesarea (SC), dan tidak mendapatkan konseling mengenai IMD sebelum atau selama hamil maka saat melahirkan tidak melakukan IMD (Kambale et al., 2018). Namun keberhasilan IMD tidak hanya dari faktor ibu, dimana menurut penelitian Al Dasoqi et al. (2018) menyatakan bahwa perlu peningkatan awareness tentang peraturan pelayanan persalinan dan prosedur inisiasi menyusu dini dan pemberian ASI eksklusif. Perlu dukungan dari petugas kesehatan, peraturan rumah sakit yang mendukung adanya IMD dan peraturan dari pemerintah mengenai IMD dan pemberian ASI eksklusif.

Setelah dilakukan IMD hal yang harus dilakukan selanjutnya adalah memberikan ASI secara eksklusif. banyak faktor yang mempengaruhi keberhasilan pemberian ASI eksklusif, penelitian yang dilakukan Widaryanti (2016) pengetahuan ibu mempengaruhi pemberian ASI eksklusif dengan $\mathrm{OR}=6$, semakin tinggi pengetahuan ibu mengenai manajemen laktasi maka ibu akan berhasil daalam pemberian ASI eksklusif. selain dari tingkat pengetahuan faktor lain yang mendukung keberhasilan pemberian ASI eksklusif adalah dukungan dari keluarga maupun tenaga kesehatan. hal ini didukung oleh Widaryanti \& Rossalia (2018) dukungan tenaga kesehatan yang terlatih akan membantu keberhasilan pemberian ASI eksklusif. Jika ibu mengalami permasalahan dalam proses menyusui maka petugas kesehatan akan memberikan solusi sehingga meningkatkan cakupan ASI eksklusif. Penelitian lain yang dilakukan oleh Victora et al. (2016) pemberian ASI eksklusif memberikan efek jangka pendek dan jangka panjang. anak yang diberikan ASI mempunyai IQ lebih tinggi dibandingkan anak yang tidak mendapatkan ASI. Penelitiaan yang dilakukan oleh Widaryanti (2019b) diperoleh hasil terdapat hubungan antara pemberian MP ASI terhadap kejadian stunting pada balita dengan p-value $<0.05$, dan hasil r 0.643 menunjukan hubungan antara praktik pemberian MP ASI dengan kejadian stunting memiliki keeratan yang kuat. Pemberian MP 
ASI yang tepat dapat memenuhi kebutuhan nutrisi anak, sehingga tidak terjadi kekurangan zat gizi makro maupun mikro yang dapaat mengganggu pertumbuhan dan perkembangan anak. Penelitian lain yang dilakukan oleh Chiutsi-Phiri et al. (2017) menyebutkan terdapat peningkatan pengetahuan setelah mendapatkan penyuluhan nutrisi, pengetahuan meliputi variasi menu seimbang, praktik menyiapkan MP ASI yang hygienis dan cara memberikan MP ASI.

\section{KESIMPULAN}

Kegiatan sosialisasi ini sangat bermanfaat terhadap perubahan pengetahuan peserta tentang pemberian makan bayi dan anak. Hal ini dibuktikan dengan nilai $\mathrm{p}$ value 0.000 . Metode yang digunakan adalah ceramah, metode ini sudah sesuai dengan keadaan umum masyarakat. Pengabdi merekomendasikan di Dusun Sembego dilakukan pelatihan PMBA bagi kader, sehingga dapat mendampingi ibu yang memiliki balita dalam memberikan nutrisi kepada anaknya sehingga dapat menurunkan risiko terjadinya permasalahan gizi pada anak.

\section{UCAPAN TERIMA KASIH}

Terimakasih pengabdi ucapkan untuk Universitas Respati Yogyakarta yang telah memberikan support kepada peneliti untuk melakukan kegiatan ini. Selain itu pengabdi juga mengucapkan terimakasih kepada perangkat Desa maguwoharjo yang telah memberikan Ijin dan memberikan kesempatan untuk melaksanakan kegiatan ini.

\section{REFERENSI}

Al Dasoqi, K., Safadi, R., Badran, E., Basha, A.S., Jordan, S., Ahmad, M. 2018. Initiation and continuation of breastfeeding among Jordanian first-time mothers: a prospective cohort study. International Journal of Women's
Health.

10:571-577.

https:/ /dx.doi.org/10.2147/IJWH.S175850

Chiutsi-Phiri, G., Heil, E., Kalimbira, A.A., Masangano, C., Mtimuni, B.M., Krawinkel, M.B., Jordan, I. 2017. Reduced Morbidity Motivated Adoption of Infant and Young Child Feeding Practices after Nutrition Education Intervention in Rural Malawi. Ecology of Food and Nutrition. 56(4):329348. https://doi.org/10.1080/03670244.2017.13381 81

Di Renzo, L., Colica, C., Carraro, A., Goga, B.C., Marsella, L.T., Botta, R., Colombo, M.L., Gratteri, S., Chang, T.F.M., Droli, M., Sarlo, F., De Lorenzo, A. 2015. Food safety and nutritional quality for the prevention of non communicable diseases: the Nutrient, hazard Analysis and Critical Control Point process (NACCP). Journal of Translational Medicine. 13:128. https://dx.doi.org/10.1186/s12967-015-04842

Dinas Kesehatan Kabupaten Sleman. 2018. Profil Kesehatan Kabupaten Sleman. Yogyakarta: Dinas Kesehatan Kabupaten Sleman.

Hardianti, R., Dieny, F.F., Wijayanti, H.S. 2018. Picky eating dan status gizi pada anak prasekolah. Jurnal Gizi Indonesia (The Indonesian Journal of Nutrition). 6(2):123-130. https://doi.org/10.14710/jgi.6.2.123-130

Kambale, R.M., Buliga, J.B., Isia, N.F., Muhimuzi, A.N., Battisti, O., Mungo, B.M. 2018. Delayed initiation of breastfeeding in Bukavu, South Kivu, eastern Democratic Republic of the Congo: a cross-sectional study. International Breastfeeding Journal. 13:6. https://dx.doi.org/10.1186/s13006-018-01504

Khatoon, T., Mollah, M.A., Choudhury, A.M., Islam, M.M., Rahman, K.M. 2011. Association between infant- and child-feeding index and nutritional status: results from a cross-sectional study among children attending an urban hospital in Bangladesh. Journal of Health Population and Nutrition. 29(4):349-356. https://doi.org/10.3329/jhpn.v29i4.8450

Murtiyarini, I., Herawati, D.M.D., Afriandi, I. 2014. Evaluasi Pelaksanaan Konseling Menyusui. Kesmas: Jurnal Kesehatan Masyarakat Nasional. 
9(1):78-86.

http://dx.doi.org/10.21109/kesmas.v9i1.460

Permatasari, T.A.E., Sartika, R.A.D., Achadi, E.L., Puwono, U., Irawati, A., Ocviyanti, D., Martha, E. 2016. Does Breastfeeding Intention Among Pregnant Mothers Associated with Early Initiation of Breastfeeding? Jurnal Kesehatan Reproduksi. 7(3):169-184. http://dx.doi.org/10.22435/kespro.v7i3.6278. $169-184$

Sholikah, A., Rustiana, E.R., Yuniastuti, A. 2017. Faktor Faktor yang Berhubungan dengan Status Gizi Balita di Pedesaan dan Perkotaan. Public Health Perspective Journal. 2(1):9-18.

Victoria, C.G., Bahl, R., Barros, A.J., Franca, G.V., Horton, S., Krasevec, J., Murch, S., Sankar, M.J., Walker, N., Rollins, N.C., Lancet Breastfeeding Series Group. 2016. Breastfeeding in the 21st century: epidemiology, mechanisms, and lifelong effect. Lancet. 387(10017):475-490. https://doi.org/10.1016/S01406736(15)01024-7

WHO, UNICEF. 2011. Pelatihan konseling menyusui modul 40 jam: panduan peserta. Jakarta: WHO/UNICEF.

Widaryanti, R. 2016. Determinan Pemberian ASI Eksklusif di Puskesmas Wedi Kabupaten Klaten Jawatengah Tahun 2015. Medika Respati: Jurnal Ilmiah Kesehatan. 11(4):52-68. https://doi.org/10.35842/mr.v11i4.190

Widaryanti, R., Rosalia, I.P.P. 2018. Evaluasi Pasca Pelatihan Konseling Menyusui Terhadap Peningkatan Cakupan ASI Eksklusif di Kota Yogyakarta. Medika Respati: Jurnal Ilmiah Kesehatan. 13(4):9-16. https://doi.org/10.35842/mr.v13i4.192

Widaryanti, R. 2019a. Pemberian Makan Bayi dan Anak. Yogyakarta: Penerbit Deepublish.

Widaryanti, R. 2019b. Makanan Pendamping ASI Menurunkan Kejadian Stunting pada Balita Kabupaten Sleman. Jurnal Ilmiah Kesehatan ArRum Salatiga. 3(2):23-28. 